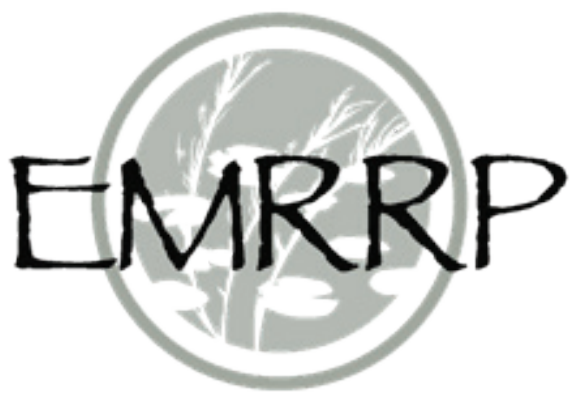

\title{
HEC-RAS-RVSM (Riparian Vegetation Simulation Module)
}

by Zhonglong Zhang, Billy Johnson, and Blair Greimann

PURPOSE: The purpose of this Ecosystem Management and Restoration Research Program (EMRRP) technical note (TN) is to document the riparian vegetation simulation module (RVSM) developed and integrated with the Hydrologic Engineering Center-River Analysis System (HECRAS) (http://www.hec.usace.army.mil/software/hec-ras). The RVSM simulates spatially distributed seed dispersal, establishment, growth, and removal in response to dynamic hydraulic conditions. The HEC-RAS-RVSM is designed to model the interactions between flow and riparian vegetation in the floodplain and support the river ecosystem management and restoration.

BACKGROUND: Riparian zones are long strips of vegetation adjacent to streams, rivers, lakes, reservoirs, and other inland aquatic systems (Fischer and Fischenich 2000). Riparian zones range in width from a few to hundreds of meters. Riparian vegetation is diverse in species and is associated with nearly all continental freshwater bodies and forms diverse ecotones between the aquatic and terrestrial environments. The riparian zone plays a significant role in controlling channel morphology, maintaining a favorable habitat for aquatic organisms, and improving river water quality (Tabacchiet al. 1998; Perucca et al. 2007). Riparian vegetation increases the bank resistance against erosion directly by root binding, and indirectly by enhancing local deposition of organic material and fine sediment, which increases the soil cohesion (Tal et al. 2004). By trapping organic matter and sediment as well as assimilating excessive nutrients, riparian vegetation has a strong ability to mitigate nutrients and contaminant content of adjacent rivers (Comerford et al. 1992; Dosskey et al. 2010). Riparian habitats also provide diverse foraging and breeding sites that support the coexistence of many wildlife species (Tucker and Wayne 1990). The removal and modification of vegetation in riparian areas have been common land management practices in the past; the practices have had a number of significant impacts on the health of both terrestrial and aquatic ecosystems. Moreover, as a result of widespread loss and degradation of global riparian habitat, riparian vegetation rehabilitation has become an important component for many river restoration programs (Rood et al. 2005; Merritt et al. 2010).

The flow regime is the main driver of channel morphology through its influence on sediment transport and channel structure. The characteristics of riparian ecosystems are directly and indirectly determined by the streamflow regime, and changes in flow regime directly and indirectly affect those ecosystems. Although substantial research has been directed towards exploring vegetated open channel hydraulics and riparian vegetation interactions, there are at present no comprehensive techniques for modeling complex internal relationships and interactions between flow and vegetation, predicting riparian vegetation's response to fluvial processes, and evaluating alternative operations and management plans. Most of the existing riparian vegetation models, such as Riparian Ecosystem Management Model (REMM), have not linked with river hydraulics 
and sediment transport simulation. SRH-1DV, developed by the U.S. Bureau of Reclamation (USBR), might be the first coupled one-dimensional (1-D) river hydraulic, sediment, and vegetation model applied for modeling the interactions of flow and riparian vegetation (Fotherby et al. 2012). The SRH-1D is USBR's 1-D hydraulics and sediment transport model.

The goal of this study was to create a tool that incorporates river hydraulics with vegetation lifecycle processes in support of riparian vegetation habitat management and restoration. The base of the RVSM is the riparian vegetation component included in the SRH-1DV model. The RVSM simulates lifecycles of riparian vegetation species using slice polygons instead of crosssection points used in SRH-1DV. Advantages of the polygon-based riparian vegetation model are (1) to better represent the spatial distribution of real-world riparian vegetation, (2) to fit for coupling with both 1-D and two-dimensional (2-D) flow models, and (3) to directly overlay model results with a vegetation map for performing spatial analysis of riparian vegetation distribution. In addition, eleven vegetation roughness computation equations were incorporated into the RVSM. The RVSM was integrated into the HEC-RAS 1-D unsteady and quasi-unsteady flow model to assist in ecosystem management and restoration projects. The HEC-RAS simulates riverine hydraulics and performs mobile-bed sediment transport. Both capabilities are critically important when quantifying the life-cycles of various vegetation species and the interactions of flow regime and riparian vegetation. The HEC-RAS model was chosen also because it has been continuously developed and supported by the U.S. Army Corps of Engineers (USACE) and widely used in the U.S. and the world. Most large river systems as well as many smaller rivers and streams in the U.S., have already been modeled with HEC-RAS.

RVSM (RIPARIAN VEGETATION SIMULATION MODULE): The RVSM simulates the life-cycle of vegetation on the floodplain and computes dynamic hydraulic roughness for the 1-D river model. Hydraulic roughness coefficients in this document refer primarily to Manning's $n$. This section briefly describes the major processes in RVSM and interactions with HEC-RAS.

Vegetation Classification and Representation. Vegetation species on the riparian zone are classified into certain types. Vegetation types simulated in the model can be a species, an alliance of species, or a land-use designation. Multiple species that have similar lifecycles may also be simulated as one type; for example, several grass species are often grouped into one type-herbs. In general, a special vegetation type, called "no grow," is defined to represent the agricultural, industrial, and urban land on floodplains. This vegetation type just occupies the space and prevents the colonization of other vegetation types. The lifecycle for each vegetation type is simulated individually. SRH-1DV has been applied to simulate a variety of riparian vegetation types; approximately twenty vegetation types were modeled by the USBR for the Sacramento River, San Joaquin River, and Rio Grande River by the USBR (USBR, 2009; Fotherby et al. 2012). Table 1 provides a list of riparian vegetation types represented and modelled for three river ecosystems.

For each vegetation type, plant organs such as the root, stem, and leaves are quantified using the following indicators: plant height, canopy height, canopy width, stem diameter, number of stems, and root depth. The canopy height and width of herbaceous vegetation are often set to 0 . These plant characteristics are simulated because they are either factors impacting hydraulic roughness or factors such as root depth affecting plant survival and growth. Figure 1 (left) illustrates a typical plant represented in RVSM. 


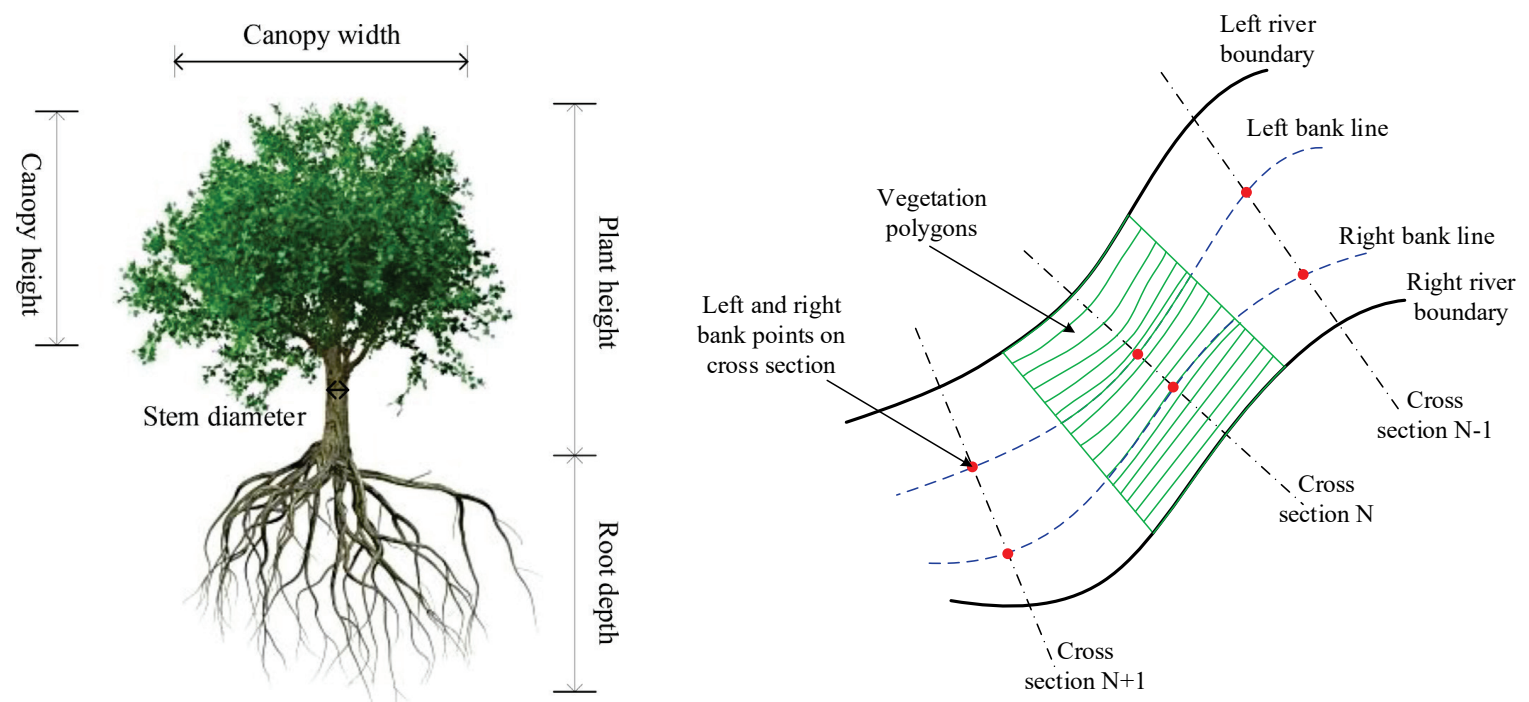

Figure 1. Left: Representation of a typical plant in RVSM. Right: Vegetation computation mesh created based on river cross sections.

Table 1. Riparian vegetation types previously modeled by the RVSM.

\begin{tabular}{|c|c|c|c|}
\hline Vegetation Type & Latin Name & Abbreviation & River \\
\hline Freemont cottonwood & Populus fremontii & $\mathrm{Fc}$ & $\begin{array}{l}\text { Sacramento, San Joaquin, and } \\
\text { Rio Grande }\end{array}$ \\
\hline $\begin{array}{l}\text { Sandbar/narrow leaf/coyote } \\
\text { willow }\end{array}$ & Salix exigua & Sbw & $\begin{array}{l}\text { San Joaquin, Sacramento, and } \\
\text { Rio Grande }\end{array}$ \\
\hline Arundo* & Arundo donax & Arun & San Joaquin, Sacramento \\
\hline Red sesbania/scarlette wisteria* & Sesbania punicea & Rs & San Joaquin \\
\hline Gooding's black willow & Salix gooddingii & Gbw & Sacramento, Rio Grande \\
\hline Oregon ash & Fraxinus latifolia & Oash & San Joaquin \\
\hline Elderberry & Sambuscus & eld & San Joaquin \\
\hline California wildrose & Rosa californica & rose & San Joaquin \\
\hline Salt grass & Distichlis spicata & salt & San Joaquin \\
\hline Bearded (creeping) rye grass & Leymus triticoides & crye & San Joaquin \\
\hline California mugwort /sagebrush & Artemisia californica & mug & San Joaquin \\
\hline California bulrush & $\begin{array}{l}\text { Schoenoplectus } \\
\text { californicus }\end{array}$ & Cbr & San Joaquin \\
\hline Buttonbush willow & $\begin{array}{l}\text { Cephalanthus } \\
\text { occidentalis }\end{array}$ & bbw & San Joaquin \\
\hline Seep willow/mulefat & Baccharis salicifolia & mule & Rio Grande \\
\hline Honey mesquite & Prosopis glandulosa & $\mathrm{hmq}$ & Rio Grande \\
\hline Four-wing saltbush & Atriplex canescens & fwsb & Rio Grande \\
\hline Broad-leaved cattail & Typha latifolia & catt & Rio Grande \\
\hline Russian olive* & Elaeagnus angustifolia & Rolv & Rio Grande \\
\hline Tamarisk/salt cedar* & Tamarix sp. & tam & Rio Grande \\
\hline Mixed forest & $N A$ & $m \times f$ & Sacramento \\
\hline
\end{tabular}

Note: * invasive species. 
Vegetation Computation Mesh. The riparian zone for the HEC-RAS model domain must be discretized into a computation mesh for a RVSM simulation. The vegetation mesh consists of an array of parallel slice polygons along the channel bank. The vegetation slice polygon (mesh) is the basic unit of vegetation computation in RVSM. Hydraulics, groundwater, and vegetation conditions within the polygon (mesh) are treated as a homogeneous computation cell in RVSM. Vegetation slice polygons must cover the entire riparian zone model domain. Figure 1 (right) shows how a typical vegetation mesh with slice polygons is created between two cross sections in HEC-RAS. First, a middle line is interpolated to divide two adjacent cross sections. A userdefined number of slice polygons between two middle lines along the river are created within the left and right boundaries of the riparian zones. Using a vegetation computational mesh created with this approach, hydraulic and groundwater information from the HEC-RAS 1-D model and groundwater module can automatically be passed into the slice polygons in RVSM.

The vegetation slice polygons must be numbered from the upstream to the downstream and from the left to the right along the cross section. Figure 2 illustrates a vegetation computation mesh with the assigned slice polygon id.

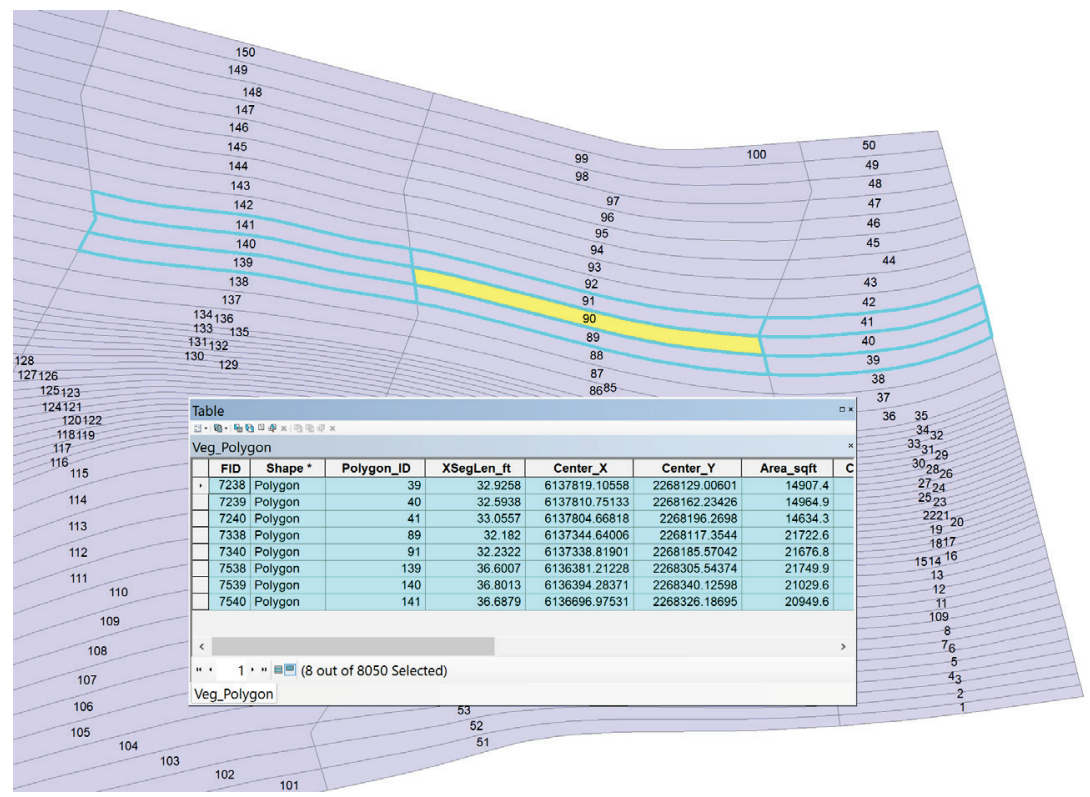

Figure 2. Vegetation computation mesh with assigned slice polygon id.

Vegetation distribution in the real world is often given as a GIS map and used to define the initial establishment of vegetation for each slice polygon, while in the model it is represented by the existence or absence of vegetation within the vegetation computational mesh. Initial vegetation conditions for the model domain must be defined first for a RVSM simulation. By overlapping a vegetation map with vegetation computational mesh, initial distribution of simulated vegetation types is set to slice polygons. Figure 3 (left) shows an example of assigned initial distribution of three modeled vegetation types to slice polygons based on vegetation GIS mapping and vegetation computation mesh (Figure 3(right)). It is important to note that multiple vegetation types can coexist in the polygon, but each vegetation type must be in the same age group in the polygon. Initial ages of vegetation types are user-defined inputs. 

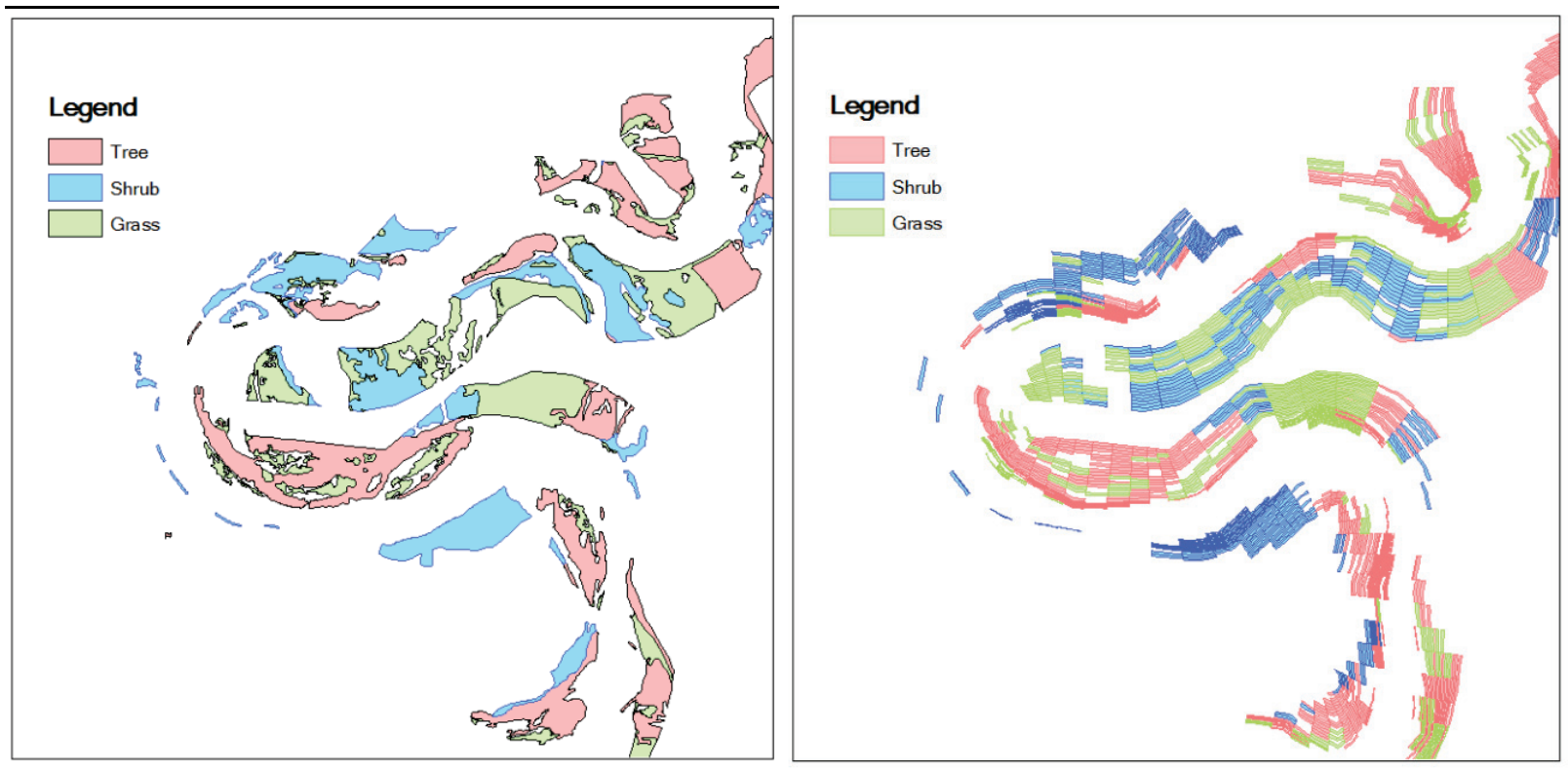

Figure 3. Left: Vegetation map. Right: initial distribution of modeled vegetation types based on the slice polygons created for RVSM.

Vegetation Lifecycle Simulation. The RVSM simulates the lifecycle of vegetation, including seed dispersal, seedling establishment, and plant growth and mortality in response to dynamic physical conditions.

\section{Plant Establishment}

In RVSM, plant establishment simulates the seed germination and lateral root spread. Presently, only one type of seed germination is included (e.g., air dispersal). Another type, germination due to water dispersal, might be included in the future. Established plants are also allowed to be expanded to adjacent points through lateral spread of roots. Figure 4 shows the flowchart of the model representation for plant establishment. Plant establishment simulates the seed germination and lateral root spread.

During seed dispersal season, seeds are available to certain vegetation polygons in the model domain. Seedlings are only established within the vegetation polygons according to seed availability and suitability criteria. A seed germinates in user-defined germination seasons when groundwater capillary fringe reaches ground surface, and no other vegetation types in the same polygon prevent its germination (Fotherby et al. 2012). 


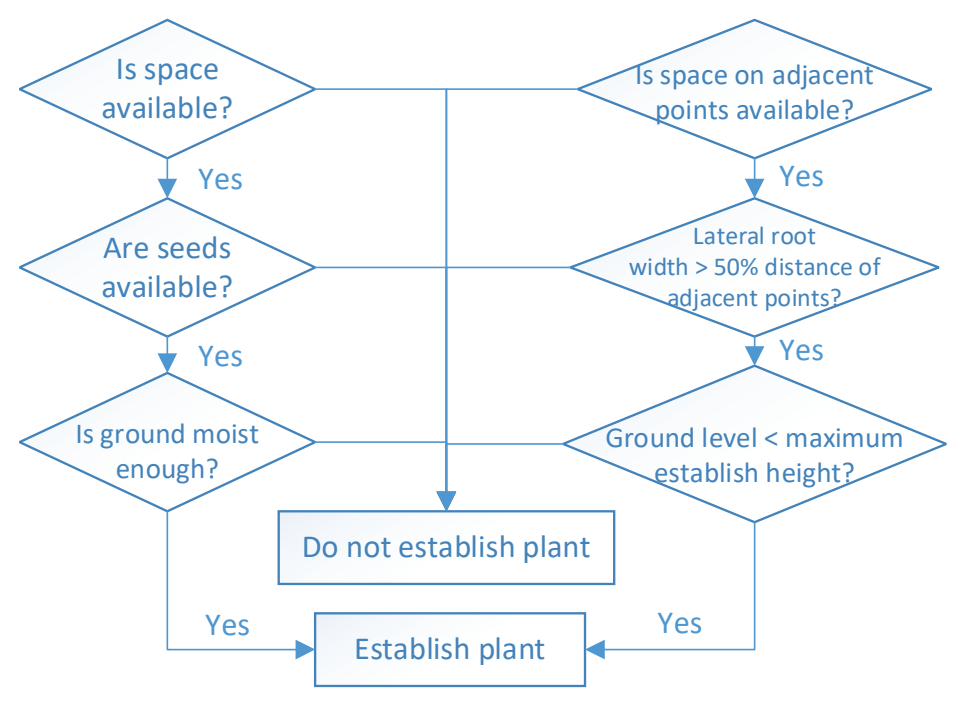

Figure 4. Plant establishment processes simulated in RVSM.

If an air dispersal for the plant germination is being simulated, a plant is assumed to germinate if the following three criteria are satisfied: (1) available space, (2) available seeds, and (3) moist soil.

The "available space" criterion is met if no other vegetation is present at that location that would outcompete the plant. A plant type can establish if all of the following conditions are met: (1) an older plant of the same type is not already growing at that polygon, (2) competition rules for other established plants do not prevent the germination, and (3) the plant type is tolerant of existing shade conditions at that location.

The "available seeds" criterion determines whether or not seeds are available to germinate. Start and end days for seed germination can be user-specified or calculated by total degree-day method. The seed germination must occur between the start and end date for a plant to establish. In RVSM, it is assumed that an unlimited number of seeds are available between the start and end dates. It is also assumed that seed can be distributed throughout the study area, regardless of the presence or absence of mature plants. Also, the start and end days for the seed germination can be calculated according to the arrival date of the total degree-days needed for the seed release and the allowable duration of the seed release. If the total degree-day method is selected, users need to provide daily air temperature records and specify the parameters, including base temperature, total degree-days, and duration for the seed release.

The "moist soil" criterion determines whether the soil has suitable soil moisture for the seed to begin a germination. For each plant type, the user needs to define a distance above the groundwater table in which the seed is allowed to germinate. Also, the user defines a specified maximum number of days when the ground surface is above this distance prior to seed germination. This accounts for the time that the soil remains moist after the river stage recedes. Additionally, the soil should not be too wet for the seed to germinate. Thus, the depth below the groundwater table where a germination can still occur is required. Plants with no ability to 
germinate underwater are assigned the depth below the groundwater table with $0.01 \mathrm{ft}$ and plants with more tolerance can have values of 0.2 to $0.5 \mathrm{ft}$.

In RVSM, a lateral root spread is included to represent plants that expand coverage area through root growth. The parameters of this category are included in the plant establishment section. Lateral root growth can also be used as a mechanism to represent the spread of plants through rhizomes or stolon. Once the root or rhizome extends half the distance to the next lateral cross section point, or points, on the next cross section upstream or downstream, the adjacent point is colonized by this plant. Lateral spread to an adjacent cross section is rare since cross section spacing is commonly greater than extension of the plant for the period considered. Lateral root spread rate of each month is specified for each plant type. Moreover, there is a maximum height limit above the groundwater level at which plant root spread can still occur.

\section{Plant Growth}

After the seed germination, plant growth is simulated by tracking growth of the following individual organs: root, stem, and canopy as shown in Figure 1 (left). The growth of plant root and stem is computed according to user-defined growth rates. The growth rates are specified for each month and age group. The root growth stops when reaching the maximum root depth or a user-specified depth with respect to groundwater table. The stem growth also stops when the maximum height is reached. The canopy height, width, and stem diameter are computed from empirical relationships with plant height. A power relationship given below is used to quantify the relationship between the plant height and its stem diameter (Hulshof et al. 2015). The canopy height and its width are assumed to be constant ratios of plant height.

$$
H_{p}=a D^{b}, \quad H_{c}=\alpha H_{p}, \quad W_{c}=\beta H_{p}
$$

Where, $H_{p}$ is plant height, $H_{c}$ is canopy height, $W_{c}$ is canopy width, $D$ is stem diameter, and $a, b$, $\alpha, \beta$ are species-specific empirical coefficients.

Plant growth can occur when external conditions such as season, temperature and groundwater level are suitable. Presently, plant growth processes are only controlled by user-specified growth rates and the maximum growth extension. The impacts of external conditions, such as soil moisture and nutrients on plant growth will be considered in the future.

User-specified growth rates for the roots, stalks, and canopy are based upon the month and age of the plant; that is, a growth rate can be assigned for each month of the first year, and then different growth rates can be assigned for each subsequent year of plant life. Root growth is computed at the specified rates until reaching an assigned maximum root depth or a userspecified depth with respect to the groundwater table. Stalk growth and canopy width are also computed and tracked in the plant growth component until the plant reaches an assigned maximum height or width for the vegetation type.

\section{Plant Mortality}

Riparian vegetation can be removed during the model simulation period. Multiple mechanisms may result in plant mortality and be removed from the model domain. The following 
mechanisms are included in RVSM: (1) Desiccation: two methods are available to simulate desiccation death. The root-depth method supposes desiccation death occurs if the root tip is above the capillary fringe for certain days. The cumulative stress method calculates water stress based on the groundwater level decline rate. This method is described in detail in the next paragraph. (2) Drowning: when vegetation is submerged for certain days. (3) Scour: when flow velocity becomes greater than the maximum velocity a plant can stand. (4) Competition: if other vegetation types within the same polygon outcompete this plant (e.g., invasive species reaching a certain age may displace or kill some native species). (5) Senescence: if plant age exceeds the maximum allowable age. The basic time step of the vegetation simulation is daily, however, it is adjustable. Figure 5 shows the decisions and flowchart for the plant removal processes.

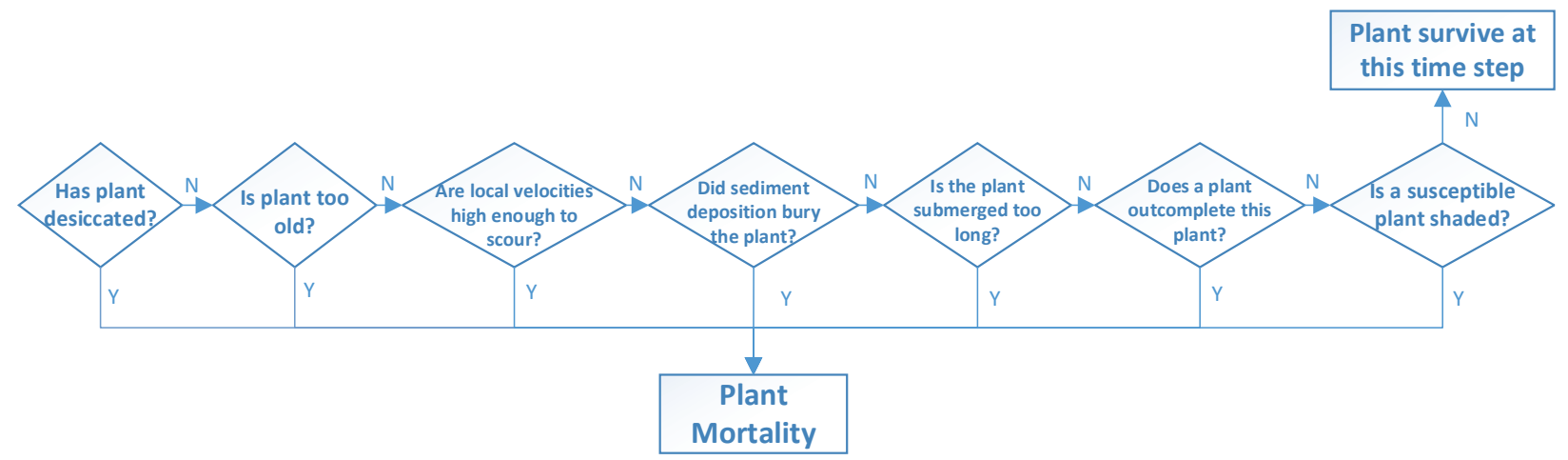

Figure 5. Plant mortality processes simulated in RVSM.

Desiccation. Desiccation can be a dominant method of mortality, especially in the southwest of arid and semiarid basins. If a plant experiences too much stress due to lack of water, then the plant will die. Two methods, time of separation and water stress, are used to predict desiccation, both of which depend on the relative location of the root and capillary fringe. The capillary fringe is assumed to be a constant distance above the groundwater elevation for a particular cross section.

The "time of separation" method assumes that desiccation death occurs when the root is separated from the capillary fringe for a user-specified number of days. This method tracks the relative elevation of the plant root and the capillary fringe. When a plant is a user-specified distance above the capillary fringe of the water table for more than the number of days specified, the critical time of separation is reached. The critical time of separation can also be a function of plant age. The user can vary each plant's resistance to desiccation with age.

The other method of desiccation tracks a "water-stress" variable. When the value of that variable exceeds a user-specified value, then desiccation death occurs. The water stress parameter can increase or decrease every time step, depending upon whether the plant is experiencing or recovering from water stress. The user enters a desiccation table of water stress values (desiccation rates) versus a water table decline rate where a negative desiccation rate indicates recovery. If the water table is declining faster than the root can grow, the desiccation rate is positive and the plant will eventually die. However, if the water table rises or stabilizes, the desiccation rate is negative. The relationship between rate of desiccation and rate of water table decline for each plant type is a function of soil type. Figure 6 presents the relationship for the 
rate of change in a unitless water stress parameter as a function of water table decline derived for Fremont cottonwood (Populus fremontii) (Fotherby et al. 2012).

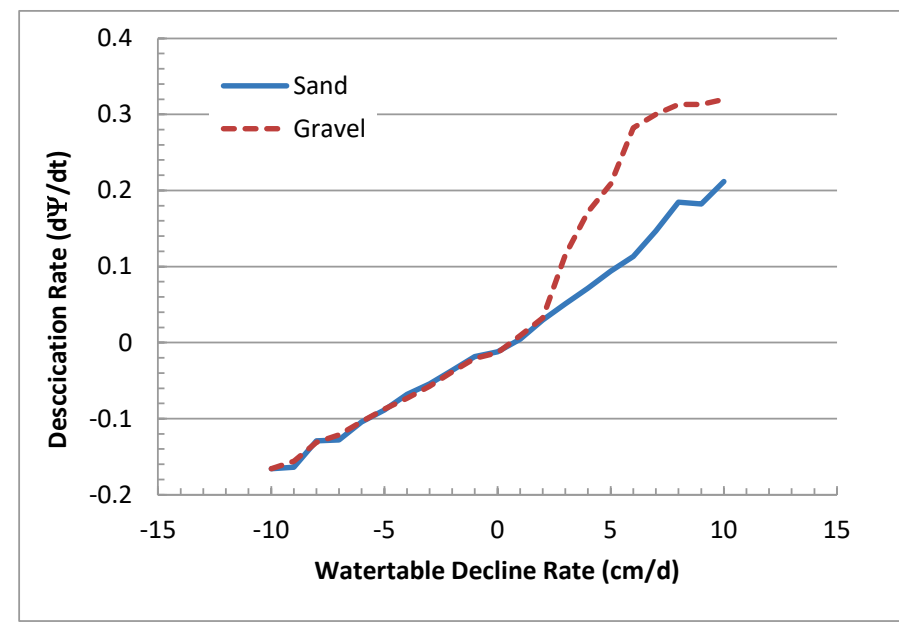

Figure 6. Desiccation/recovery rates for sand and gravel sediment as a function of water table decline rate.

Senescence (Age). Mortality due to age occurs when the plant becomes older than the userspecified age. The age of death is set for each plant type. All plants of the same type and age will die concurrently on the day the specified age is reached. Senescence is valuable for projects with multi-decadal simulation periods, or where there is a high percentage of old groves of woody plants.

Scour. Plant removal by scour is a function of cross-sectional averaged flow velocity in the channel or in the overbank area. If a plant is less than the age specified, and the root crown is inundated by flow, the plant will be removed by scour when the channel or overbank flow reaches the average critical velocity. This critical-scour velocity value can be assigned as a function of plant age in RVSM.

Burial. Plant burial occurs when sediment is deposited during the falling limb of a high-flow event. The loss of plants from large deposits can be tracked in RVSM because it links vegetation growth processes with flow and sediment transport in HEC-RAS. Mortality due to burial occurs when sediment deposited at the site of the plant exceeds the plant height by a user-specified depth.

Inundation. Mortality due to inundation occurs when the root crown of a plant is submerged by an assigned depth and for an extended duration. The threshold duration of inundation and the depth of inundation above the root crown can be entered as a function of age. Similar to desiccation, plant mortality due to inundation can be readily studied in the laboratory.

Competition. Competition is implemented through a matrix for each plant type; the matrix contains the competition rules for when the other plant types (plant Y) can outcompete the current plant types (plant $\mathrm{X}$ ) based on plant age. The competition matrix is initially used to identify whether a plant type is able to germinate at a point where the other plants have existed. 
In the competition table, the age of the Y plants indicate when they are old enough to eliminate plant $\mathrm{X}$ at the specified age. A value of 99 indicates that species $\mathrm{Y}$ will not be able to remove species $X$ at its specified age (if initial age plus the years of the simulation are less than 99). Nogrow and agricultural lands were always assigned 0.01 to immediately remove any attempted plant growth (i.e., no X plants were allowed to grow at the $\mathrm{Y}$ plant locations of no grow). For example, a new cottonwood seedling could be prevented from establishing whether three-yearold grass, a two-year-old invasive plant, or an agricultural plant of any age is already present at the point.

Shading. Plants can be prevented from growing in areas that are shaded. A canopy growth function is added to the growth component to track locations of shade. The shaded area around each plant is determined based on age of the plant and growth rate of the canopy specified by month. During simulation, the model computes if the plant is shaded by other vegetation at that point or by vegetation on adjacent points. The user can enter the age at which the plant becomes shade tolerant. If the plant is younger than this age and located within the shaded area, death due to shading will occur.

Hydraulic Roughness. Average velocity in rivers is commonly calculated using a Manning's equation:

$$
U=\frac{c R^{1 / 6}}{n} \sqrt{R S_{f}}
$$

Where, $U=$ cross-section averaged velocity, $R=$ hydraulic radius, $S_{f}=$ friction or energy slope, $n$ $=$ Manning's roughness coefficient, $c$ is a unit correction factor.

In hydraulic modeling, Manning's $n$ is typically estimated from narrative descriptions of channel properties, by comparing photographs of rivers with known roughness values or through the model calibration. Tables of Manning's $n$ values published in Chow (1959) are the most common source for selection of channel and floodplain roughness values. HEC-RAS includes two options for specifying Manning's $n$ : (1) a fixed-value and (2) a specific value for each range of discharge.

A large number of computation methods have been developed to estimate hydraulic roughness of vegetated channels in terms of Manning's $n$. However, these numerical methods have not been coupled with 1-D hydraulic model(s) and used for computing dynamic Manning's $n$. From the immense body of vegetative roughness literature, eleven methods have emerged with generic applicability and were incorporated into the current RVSM. The first two roughness methods are suitable for grasses, the remaining nine methods are suitable for trees and shrubs. The user is allowed to select a roughness method for each vegetation type in RVSM. One of the most important considerations in vegetative roughness prediction is relative influence of plant height on flow depth. Emergent vegetation is herein defined as vegetation that is greater in height than the flow depth; submerged vegetation height is less than flow depth. The roughness computation in RVSM checks if vegetation is partially or completely submerged based on flow depth and plant height, and then uses corresponding emergent or submerged equation. If vegetation is not submerged or flow depth and velocity are 0 , Manning's $n$ value is set to 0 . 


\section{The $n$-UR method}

With respect to vegetated channels, the USDA developed an empirical technique known as the $n$ $U R$ curve for calculating roughness of grass-lined channels (Ree 1954). The $n$ - $U R$ method is $5 n$ versus $U R$ curves drawn based on field experiments. For a particular vegetation type, there is a unique relationship between Manning's $n$ and the product of the mean area velocity $U$ and hydraulic radius $R$, regardless of the relative values of $U$ and $R$. Vegetation types are classified into five groups or retardance classes $(\mathrm{A}, \mathrm{B}, \mathrm{C}, \mathrm{D}, \mathrm{E}$ ), each represented by an $n$ - $U R$ curve (Figure 7). Classification and definition of vegetation cover used in $n-U R$ curves can be found from Chow (1959).

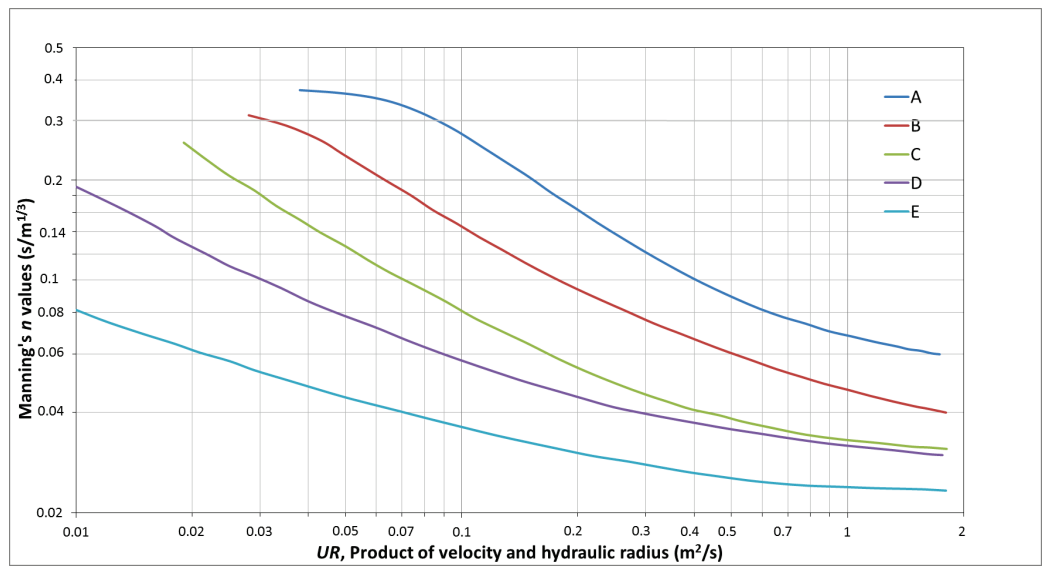

Figure 7. Typical $n-U R$ curve.

\section{Kouwen and Li 1980}

$$
n=\frac{H^{1 / 6}}{\sqrt{8 g}\left[a+b \log \left(\frac{H}{k}\right)\right]}, \quad h_{p}<H, \quad k=0.14 h_{p}\left[\frac{\left(\frac{M E I}{\gamma H S}\right)^{0.25}}{h_{p}}\right]^{1.59}
$$

Where, $H=$ flow depth, $k=$ the deflected roughness height, $g=$ gravitational acceleration, $h_{p}=$ plant height, $\gamma=$ weight density of water, $S=$ energy slope, $M E I=$ flexural rigidity, $a$ and $b=$ fitted parameters that are dependent on the relative magnitude of shear velocity $u_{*}$ and critical shear velocity $u_{*_{c r i t}}$ (Table 2 ).

Table 2. Parameters used in Kouwen and Li (1980).

\begin{tabular}{lllll}
\hline Criteria & $u_{*} / u_{*_{c r i t}} \leq 1.0$ & $1.0<u_{*} / u_{*_{c r i t}} \leq 1.5$ & $1.5<u_{*} / u_{*_{c r i t}} \leq 2.5$ & $2.5<u_{*} / u_{*_{c r i t}}$ \\
\hline$a$ & 0.15 & 0.2 & 0.28 & 0.29 \\
$b$ & 1.85 & 2.7 & 3.08 & 3.5 \\
& $u_{*}=\sqrt{g H S}$ & & \\
& $u_{*_{c r i t}}=\min \left(0.028+6.33(M E I)^{2}, 0.23(M E I)^{0.106}\right)$ & \\
\hline
\end{tabular}

Kouwen (1988) provided the following equations to compute $M E I$ for green grass and dormant grass respectively: $M E I=319 h_{p}^{3.3}$ for green grass and $M E I=25.4 h_{p}^{2.26}$ for dormant grass. 


\section{Baptist et al. 2007}

$$
\begin{array}{ll}
n=\frac{H^{1 / 6}}{\sqrt{\frac{1}{\left(1 / C_{b}^{2}+C_{d} m D h_{p} / 2 g\right)}+\frac{\sqrt{g}}{\kappa} \ln \left(\frac{H}{h_{p}}\right)},} & h_{p}<H \\
n=H^{1 / 6} \sqrt{1 / C_{b}^{2}+C_{d} m D H / 2 g}, & h_{p} \geq H
\end{array}
$$

Where, $C_{b}=$ Chézy resistance coefficient of the bed, $C_{d}=$ drag coefficient, $m=$ stem density, $D=$ stem diameter, $\kappa=$ von Kármán constant $=0.40-0.41$.

\section{Huthoff et al. 2007}

$$
\begin{array}{cc}
U=\left\{\begin{array}{cc}
\sqrt{\frac{2 g S}{C_{d} m D}}, & h_{p} \geq H \\
\left(\sqrt{\frac{h_{p}}{H}}+\frac{H-h_{p}}{H}\left(\frac{H-h_{p}}{s}\right)^{\frac{2}{3}}\left(1-\left(\frac{H}{h_{p}}\right)^{-5}\right)\right) \sqrt{\frac{2 g S}{C_{d} m D}}, & h_{p}<\mathrm{H}
\end{array}\right. \\
s=\sqrt{\frac{1}{m}}-D, n=\frac{H^{2 / 3} \sqrt{S}}{U} &
\end{array}
$$

Where, $U=$ average flow velocity, $s=$ separation between individual plants, $S=$ energy slope.

\section{Cheng 2011}

$$
C= \begin{cases}\sqrt{\frac{\pi g(1-\lambda)^{3} D}{2 C_{d} \lambda H}}, & h_{p} \geq H \\ \sqrt{\frac{\pi g(1-\lambda)^{3} D}{2 C_{d} \lambda h_{p}}\left(\frac{h_{p}}{H}\right)^{3 / 2}+4.54 \sqrt{g}\left(\frac{h_{s}}{D} \frac{1-\lambda}{\lambda}\right)^{1 / 16}\left(\frac{h_{s}}{H}\right)^{3 / 2},} & h_{p}<H \\ \lambda=m \frac{\pi D^{2}}{4}, n=\frac{H^{1 / 6}}{C} & \end{cases}
$$

Where, $C=$ Chézy coefficient, $\lambda=$ fraction of the bed area occupied by stems, $h_{s}=H-h_{p}=$ surface layer thickness.

Freeman et al. 2000

$$
n= \begin{cases}0.00003487\left(\frac{E_{s} A_{s}}{\rho A_{p}^{*} u_{*}^{2}}\right)^{0.15}\left(m A_{p}^{*}\right)^{0.166}\left(\frac{u_{*} R}{v}\right)^{0.622}\left(\frac{R^{2 / 3} S^{1 / 2}}{u_{*}}\right), & H \leq 0.8 h_{p} \\ 0.183\left(\frac{E_{s} A_{s}}{\rho A_{p} u_{*}^{2}}\right)^{0.183}\left(\frac{h_{p}}{H}\right)^{0.243}\left(m A_{p}\right)^{0.273}\left(\frac{v}{u_{*} R}\right)^{0.115}\left(\frac{R^{2 / 3} S^{1 / 2}}{u_{*}}\right), & H>0.8 h_{p}\end{cases}
$$


Where, $E_{s}=$ modulus of plant stiffness, $A_{s}=$ total cross-sectional area of all of the stems of an individual plant measured at $H / 4, A_{p}=$ frontal area of an individual plant blocking flow, $A_{p}{ }^{*}=$ net submerged frontal area of a partially submerged plant, $v=$ fluid dynamic viscosity.

\section{Mckay and Fischenich 2011}

$$
\begin{gathered}
n=\frac{R^{1 / 6}}{\left(\frac{U}{u_{*}}\right) \sqrt{g}} \quad \text { where } \quad \frac{U}{u_{*}}=\left\{\begin{array}{lc}
\sqrt{\frac{2}{C_{d} A_{d} R}}, & H \leq h_{p} \\
\frac{2.5}{H}(X+Y), & H>1.1 h_{p}
\end{array}\right. \\
X=1.26 h_{p}{ }^{2} \frac{2 h_{p}}{11 C_{d} A_{d}}\left[1-e^{-5.5 C_{d} A_{d}}\right], \quad Y=\left(H-0.95 h_{p}\right)\left[\ln \left(\frac{H}{K h_{p}}-\frac{0.95}{K}\right)-1\right]-0.05 h_{p}\left[\ln \left(\frac{0.05}{K}-1\right)\right], K=0.13 e^{-\left(C_{d} A_{d}-0.4\right)^{2}}
\end{gathered}
$$

Where, $A_{d}=$ vegetation density per unit channel length (frontal area per unit volume).

\section{Kouwen and Fathi-Moghadam 2000}

$$
n=0.228\left(\frac{U}{\sqrt{\frac{(\xi E)}{\rho}}}\right)^{-0.23}\left(\frac{H}{h_{p}}\right)^{0.5}, \quad H \leq h_{p}
$$

where $\xi E=$ vegetation index, $\rho=$ density of water.

\section{Järvelä 2004}

Leafy tree and shrub: $\quad f=4 C_{d} \operatorname{LAI}\left(\frac{U}{U_{\chi}}\right)^{\chi} \frac{H}{h_{p}}, \quad H \leq h_{p}$

Leafless tree and shrub: $f=4 C_{d} m A_{p} \frac{H}{h_{p}}, \quad H \leq h_{p}$

$$
n=\sqrt{\frac{f}{8 g}} H^{1 / 6}
$$

Where, $f=$ Darcy-Weisbach friction factor, $L A I=$ leaf area index, $U_{\chi}=$ lowest velocity used in determining $\chi, \chi=$ vegetation parameter.

\section{Luhar and Nepf 2013}

$$
n= \begin{cases}\sqrt{\frac{C_{d} A_{d}}{2 g}} H^{2 / 3}, & H \leq h_{p} \\ \frac{1}{\left(\frac{2}{C_{f}}\right)^{1 / 2}\left(1-\frac{h_{p}}{H}\right)^{3 / 2}+\left(\frac{2}{C_{d} A_{d} h_{p}}\right)^{1 / 2}\left(\frac{h_{p}}{H}\right)} \frac{H^{1 / 6}}{\sqrt{g}}, & H>h_{p}\end{cases}
$$


Where, $C_{f}=$ friction coefficient at the bed and the interface between vegetation and open water.

Whittaker et al. 2015

$$
n=\sqrt{\frac{C_{d} A_{p}^{*} m C a^{\psi / 2}}{2 g}} H^{1 / 6} \quad, C a=\max \left(\frac{\rho U^{2} A_{p} h_{p}^{2}}{E I}, 1.0\right)
$$

Where, $C a=$ vegetative Cauchy number, $\psi=$ Vogel exponent, $E I=$ flexural rigidity of the vegetation's main stem.

Baptist et al. (2007), Huthoff et al. (2007), and Cheng (2011) are the three methods which explicitly model riparian vegetation as evenly distributed rigid cylinders. The method of Luhar and Nepf (2013) was used as a rigid vegetation method without modeling the deflection of plant height and width, because the blade-scale reconfiguration model might be suitable only for aquatic vegetation, not for most riparian shrubs and trees. The other five methods, (e.g., Freeman et al. (2000), Mckay and Fischenich (2011), Kouwen and Fathi-Moghadam (2000), Järvelä (2004), and Whittaker et al. (2015)), model the reconfiguration of flexible vegetation where roughness equations include various metrics to compute vegetation roughness coefficients. Plant density, plant height, stem diameter, canopy width and height, and LAI are used to quantify frontal projected area underwater. Modulus of plant stiffness, $E$, and flexural rigidity, EI, or $M E I$, are employed to represent stiffness of vegetation. Flow velocity, depth, and energy slope are included to take account of roughness variations with hydraulic conditions. In addition, userdefined parameters such as dimensionless drag coefficient and Vogel component are also required in some equations. The RVSM calculates a range of potential roughness values from various methods; care should be taken in selecting the method.

Manning's $n$ value of the slice polygon is dynamically computed based on the vegetation properties and flow depth, velocity, and energy slope provided by HEC-RAS. If multiple vegetation types coexist within the cross-section slice polygon, Manning's $n$ values are first computed for each vegetation type and then combined using the following equation:

$$
n_{v}=\sqrt{\sum_{i=1}^{k} n_{i}^{2}}
$$

Where, $n_{v}$ is the combined Manning's $n$ value of all the vegetation types within the cross-section slice; $i$ is the $i$ th vegetation type; $n_{i}$ is Manning's $n$ value of the $i$ th type; and $k$ is the total number of vegetation types.

After the $n$ value for riparian vegetation is computed, it is added to the user-defined Manning's $n$ value for bare river bed to obtain the total Manning's $n$ value of the cross-section slice using the equation given by Acrement and Schneider (1989) and Wu (2007):

$$
n=\sqrt{n_{v}^{2}+n_{b}^{2}}
$$


Where, $n$ is the total Manning's $n$ value for a cross-section slice, and $n_{b}$ is the Manning's $n$ value for the bare river bed.

Groundwater Module. Groundwater is a critical aspect of riparian vegetation growth. Changes in groundwater have the potential to alter the soil moisture available for uptake by plants, and may alter root architecture in those species that are sensitive to saturated soil conditions. Root depth is limited by groundwater elevation. A groundwater module is necessary to compute groundwater table and capillary fringe information required in RVSM. A simplified groundwater module is developed to compute the groundwater levels of cross sections within the model domain and coupled with RVSM. The groundwater levels are estimated based on river water surface elevation, soil hydraulic conductivity, and groundwater boundary conditions. The $1-\mathrm{D}$ groundwater governing equation is given by

$$
\frac{\partial h}{\partial t}=\frac{\partial}{\partial y}\left(h_{c} \frac{\partial h}{\partial y}\right)
$$

Where, $h$ is groundwater level (ft), $h_{c}$ is hydraulic conductivity (ft/day), y is the length along cross section.

A finite difference scheme is used to solve the governing equation. It is assumed that the groundwater flow along the cross section is 1-D. The left and right boundary conditions for each cross section are defined as $\partial h / \partial y=0$. Wherever the water surface intersects the river cross section, the groundwater levels are set to the water surface elevation as internal boundaries.

HEC-RAS-RVSM. The RVSM was coupled with unsteady state and quasi-unsteady state flow engine in HEC-RAS. The HEC-RAS model provides the following hydraulic information for vegetation computation mesh: bottom elevation, original Manning's $n$, water depth, water surface elevation, velocity and energy slope. Using water level calculated from HEC-RAS, the groundwater module computes the groundwater level and capillary fringe elevation for vegetation slice polygons. The hydraulic and groundwater information for the slice polygon is then passed into the RVSM.

In RVSM, Manning's $n$ values within the riparian zone are computed based on vegetation characteristics and hydraulic conditions along the cross section. The impacts of riparian vegetation on river hydraulics and sediment transport are fed back to HEC-RAS through updating RVSM computed Manning's $n$ values. The RVSM may be used to compute dynamic roughness coefficients for the HEC-RAS unsteady flow model and assist in the flow model calibration. The overall flowchart of the HEC-RAS-RVSM model is shown in Figure 8. 


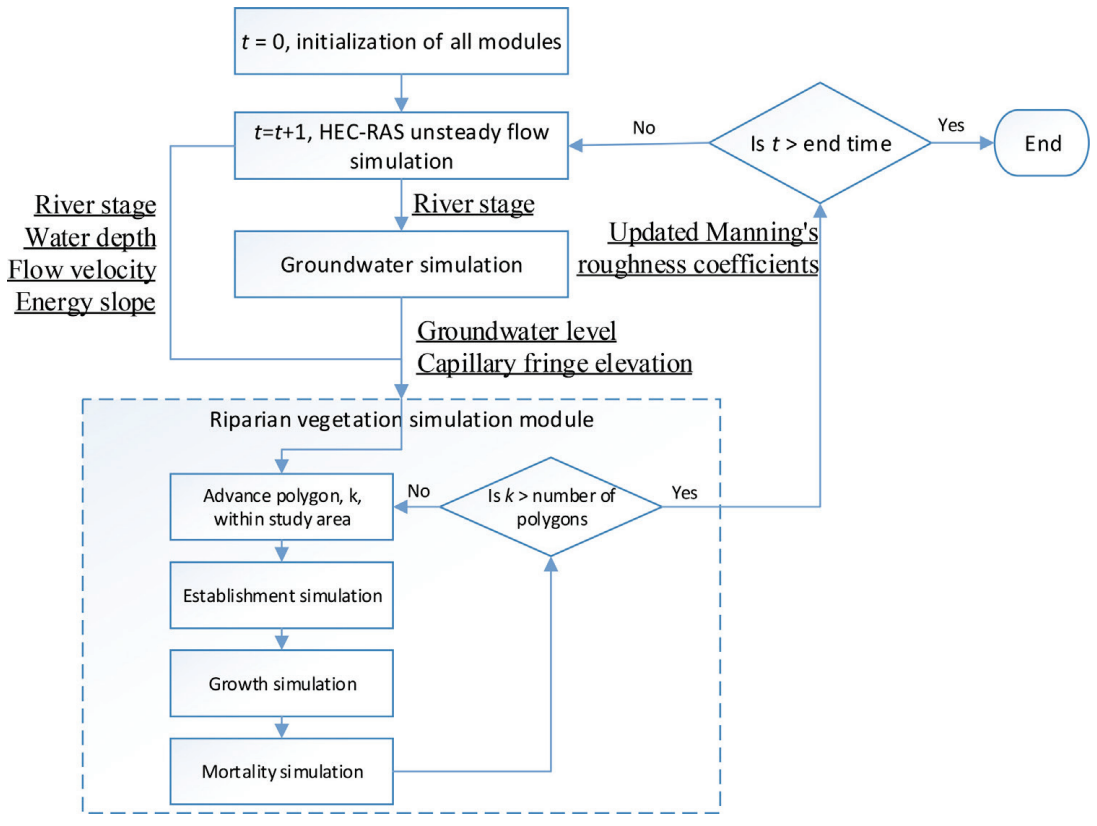

Figure 8. Flowchart of HEC-RAS-RVSM model.

RVSM INPUTS: Four vegetation input files are required to run RVSM from HEC-RAS.

"veg_polygon_neighbors.txt". This file includes two columns: the Veg slice polygon ID and ID of the individual neighbor slice polygons. The "Polygon Neighbors" tool in ArcGIS may be used to generate this information.

"veg_polygon_property.txt". This file includes two parts: (1) The hydraulic cross-section ID, the total number of Veg slice polygons along the cross section, and the length of the crosssection outside the left side of Veg slice polygons. (2) Veg slice polygon ID, the length of the Veg slice polygon along the cross-section, the $\mathrm{X}$ and $\mathrm{Y}$ coordinates of the Veg slice polygon centroid, and Manning's $n$ of bare ground within the polygon.

“initialVeg_mapping_table.txt". This file includes Veg slice polygon ID, the codes of the vegetation community, and the percentage of the Veg slice polygon within the initial vegetation map with codes of vegetation community. This file may be generated directly from overlaying a Vegetation slice polygon layer with initial vegetation map in ArcGIS.

"vegetation.txt". Five data sections are included in this file and are described as follows:

\section{RVSM simulation control and initial vegetation conditions}

VPM: vegetation computation time step (days), hydraulic roughness update time step (days), output time step (days), start and end time (days), start and end Veg polygon ID for writing detailed veg data outputs.

"VTM" model simulation period (year, month, day, hour).

"VNM" number of vegetation types, number of soil types. 
"VIV" initial vegetation map, including vegetation type, age, coverage, density, height.

Shape of vegetation

"VVN" vegetation type name.

"VVC" Veg Category: 0 = None, 1 = Tree, 2 = Shrub, 3 = Grass.

"VCR" ratio of canopy height and plant height; ratio of canopy width and stem diameter.

"VDH" allometric relationships between plant height and stem diameter: $H=a D^{b}$; unit of $\mathrm{H}$ is $\mathrm{m}$ and unit of $\mathrm{D}$ is $\mathrm{cm}$.

"VSN" number of main stems per plant.

"VLD" begin and end date of vegetation with leaves on.

\section{Plant establishment}

Presently, only one type of seed germination is included (e.g., air dispersal). Established plants are allowed to be expanded to adjacent points through lateral spread of roots. Table 3 summarizes the input parameters for the plant establishment. These parameters are applied throughout the model domain.

Table 3. Plant establishment parameters.

\begin{tabular}{|c|c|c|c|c|}
\hline Record & \multicolumn{2}{|c|}{ Parameter } & Units & Description \\
\hline \multicolumn{5}{|c|}{ Seed germination } \\
\hline MMT & \multicolumn{2}{|c|}{ Method } & & $0=$ none, $1=$ air, $2=$ water \\
\hline \multirow[t]{2}{*}{ MDY } & \multicolumn{2}{|c|}{ begin_day } & Julian day & Start day for germination \\
\hline & \multicolumn{2}{|c|}{ end_day } & Julian day & End day for germination \\
\hline \multirow[t]{3}{*}{ MDD } & \multicolumn{2}{|c|}{ base_temperature } & ${ }^{\circ} \mathrm{C}$ & $\begin{array}{l}\text { Basic temperature to calculate degree days needed } \\
\text { for seed release }\end{array}$ \\
\hline & \multicolumn{2}{|c|}{ total_degree_days } & day & Total degree days needed for seed release \\
\hline & \multicolumn{2}{|c|}{$\begin{array}{l}\text { Seed_release_durati } \\
\text { on }\end{array}$} & day & $\begin{array}{l}\text { Maximum number of days between seed release and } \\
\text { seed germination }\end{array}$ \\
\hline \multirow[t]{4}{*}{ MPR } & \multicolumn{2}{|c|}{ germ_days } & day & $\begin{array}{l}\text { Days from time seeds fall on ground until growth } \\
\text { starts during germination period }\end{array}$ \\
\hline & \multicolumn{2}{|c|}{ dry_days } & day & $\begin{array}{l}\text { Maximum number of days when ground surface was } \\
\text { above the germ_above prior to germination }\end{array}$ \\
\hline & \multicolumn{2}{|c|}{ germ_above } & $\mathrm{ft}$ & $\begin{array}{l}\text { Height above groundwater table considered moist } \\
\text { enough for germination }\end{array}$ \\
\hline & \multicolumn{2}{|c|}{ germ_below } & $\mathrm{ft}$ & $\begin{array}{l}\text { Depth below groundwater table germination can still } \\
\text { occur }\end{array}$ \\
\hline \multicolumn{5}{|c|}{ Lateral root spread } \\
\hline \multirow[t]{2}{*}{ MLT } & \multirow[t]{2}{*}{1 to $\mathrm{N}$} & age_root & & Age specified for lateral root spread rates \\
\hline & & $\begin{array}{l}\text { spread_root } \\
(1 \text { to } 12)\end{array}$ & ft/day & Lateral root spread rate each month \\
\hline MEL & \multicolumn{2}{|c|}{$\begin{array}{l}\text { max_establishment__ } \\
\text { height }\end{array}$} & $\mathrm{ft}$ & $\begin{array}{l}\text { Maximum height of plant establishment above low } \\
\text { water }\end{array}$ \\
\hline
\end{tabular}




\section{Plant growth}

The plant growth calculates vertical growth of the root (depth) and stalk (height), and the lateral growth of canopy (width). Table 4 summarizes plant growth input parameters for each vegetation type.

Table 4. Plant growth input parameters.

\begin{tabular}{|c|c|c|c|c|}
\hline Record & \multicolumn{2}{|c|}{ Parameter } & Units & Description \\
\hline GMT & \multicolumn{2}{|c|}{ Method } & & $0=$ none, 1 = stalk, canopy, root \\
\hline \multicolumn{5}{|c|}{ Stalk growth } \\
\hline \multirow[t]{2}{*}{ GST } & \multirow[t]{2}{*}{1 to $\mathrm{N}$} & age_stalk & & Age at which stalk growth rates are given \\
\hline & & $\begin{array}{l}\text { growth_stalk (1 } \\
\text { to 12) }\end{array}$ & ft/day & Stalk growth rate at each month \\
\hline GSM & \multicolumn{2}{|c|}{ max_plant_height } & $\mathrm{ft}$ & Maximum height of stalk \\
\hline \multicolumn{5}{|c|}{ Canopy expansion } \\
\hline \multirow[t]{2}{*}{ GCP } & \multirow[t]{2}{*}{1 to $\mathrm{N}$} & age_canopy & & Age at which canopy spread rates are given \\
\hline & & $\begin{array}{l}\text { growth_canopy } \\
\text { (1 to } 12)\end{array}$ & $\mathrm{ft} /$ day & Canopy spread rates at each month \\
\hline GCM & \multicolumn{2}{|c|}{ max_canopy_width } & $\mathrm{ft}$ & Maximum width of canopy \\
\hline \multicolumn{5}{|c|}{ Root growth } \\
\hline \multirow[t]{2}{*}{ GRT } & \multirow[t]{2}{*}{1 to $\mathrm{N}$} & age_root & & Age at which root growth rates are given \\
\hline & & growth_root & $\mathrm{ft} /$ day & Root growth rate at each month \\
\hline \multirow[t]{2}{*}{ GRS } & \multicolumn{2}{|c|}{ root_depth_sat } & $\mathrm{ft}$ & $\begin{array}{l}\text { Depth below groundwater table at which growth of } \\
\text { root stops }\end{array}$ \\
\hline & \multicolumn{2}{|c|}{ max_root_depth } & $\mathrm{ft}$ & Maximum depth of root \\
\hline
\end{tabular}

\section{Plant mortality}

The following mortality mechanisms are included in RVSM: desiccation, inundation (drowning), scour, competition, shading, burial, and senescence. Table 5 summarizes plant mortality input parameters required for each mechanism. 
Table 5. Plant mortality input parameters.

\begin{tabular}{|c|c|c|c|c|}
\hline Record & \multicolumn{2}{|l|}{ Parameter } & Units & Description \\
\hline \multicolumn{5}{|c|}{ Desiccation } \\
\hline YMT & \multirow{2}{*}{\multicolumn{2}{|c|}{ death id }} & & Type of desiccation simulation performed \\
\hline YID & & & & Identification number of desiccation death \\
\hline \multirow[t]{3}{*}{ YTM } & \multicolumn{2}{|l|}{ age } & year & $\begin{array}{l}\text { Age at which time and height above capillary } \\
\text { fringe is given }\end{array}$ \\
\hline & \multicolumn{2}{|l|}{ time } & day & $\begin{array}{l}\text { Number of days the root elevation must be } \\
\text { "height" above the capillary fringe to kill } \\
\text { plants }\end{array}$ \\
\hline & \multicolumn{2}{|l|}{ height } & $\mathrm{ft}$ & $\begin{array}{l}\text { Height above capillary fringe the roots must } \\
\text { be for death by desiccation }\end{array}$ \\
\hline \multirow[t]{2}{*}{ YWT } & \multirow{2}{*}{$\begin{array}{l}1 \text { to } \mathrm{N} \\
\text { (soil type) }\end{array}$} & wt_drawdown_rate & & Rate of groundwater table decline \\
\hline & & desiccation rate & & Desiccation rate for each soil type \\
\hline YMN & \multicolumn{2}{|c|}{ allowed (1 to 12$)$} & & $\begin{array}{l}\text { Indicates if desiccation can or cannot occur in } \\
\text { a given month ( } 1,0 \text { respectively) }\end{array}$ \\
\hline \multicolumn{5}{|c|}{ Senescence } \\
\hline AID & \multicolumn{2}{|l|}{ death_id } & & Identification number of age death \\
\hline ATM & \multicolumn{2}{|l|}{ max_age } & year & Age at which death occurs \\
\hline \multicolumn{5}{|c|}{ Scouring } \\
\hline SID & \multicolumn{2}{|l|}{ death_id } & & Identification number of scour death \\
\hline \multirow[t]{2}{*}{ SVC } & \multicolumn{2}{|l|}{ age } & year & Age at which critical velocity is given \\
\hline & \multicolumn{2}{|c|}{ velocity_crit } & $\mathrm{ft} /$ day & $\begin{array}{l}\text { Critical velocity above which plant is killed } \\
\text { due to scour }\end{array}$ \\
\hline \multicolumn{5}{|l|}{ Burying } \\
\hline $\mathrm{BID}$ & \multicolumn{2}{|l|}{ death_id } & & Identification number of burial death \\
\hline BDP & \multicolumn{2}{|l|}{ depth } & $\mathrm{ft}$ & $\begin{array}{l}\text { Depth of burial above top of plant required to } \\
\text { kill plant }\end{array}$ \\
\hline \multicolumn{5}{|c|}{ Inundation } \\
\hline DID & \multicolumn{2}{|l|}{ death_id } & & Identification number of inundation death \\
\hline \multirow[t]{3}{*}{ DTM } & \multicolumn{2}{|l|}{ age } & year & $\begin{array}{l}\text { Age at which time and depth above root } \\
\text { crown is given }\end{array}$ \\
\hline & \multicolumn{2}{|l|}{ time } & day & $\begin{array}{l}\text { Number of days the root crown must be } \\
\text { below "depth" to kill plant }\end{array}$ \\
\hline & \multicolumn{2}{|l|}{ depth } & $\mathrm{ft}$ & $\begin{array}{l}\text { Depth below water surface the root crown } \\
\text { must be for inundation death to take place }\end{array}$ \\
\hline \multicolumn{5}{|c|}{ Competition } \\
\hline CID & \multicolumn{2}{|l|}{ death_id } & & Identification number of competition death \\
\hline \multirow[t]{2}{*}{ CMP } & \multirow{2}{*}{$\begin{array}{l}1 \text { to } \\
\text { NVEG }\end{array}$} & age_species & & Age of plant $X$ that could be killed \\
\hline & & competition_kill_age & year & $\begin{array}{l}\text { Age of the other plants } Y \text { which could } \\
\text { outcompete plant } X \text { at given age }\end{array}$ \\
\hline Shading & & & & \\
\hline $\mathrm{CSH}$ & & Age_shade_tolerance & year & Age at which species become shade tolerant \\
\hline
\end{tabular}




\section{Vegetation roughness}

Eleven equations or methods are included in RVSM to compute riparian vegetation roughness. Table 6 summarizes roughness input parameters used in RVSM.

Table 6. Vegetation roughness input parameters.

\begin{tabular}{|c|c|c|c|}
\hline Record & Method & Parameter & Description \\
\hline RMT & & & $\begin{array}{l}0=\text { none performed, } 1=\text { RVSM computed, } 2=n \text { values } \\
\text { defined in record "RNM". }\end{array}$ \\
\hline RNM & & & $\begin{array}{l}\text { minimum } \mathrm{n} \text { value and maximum } \mathrm{n} \text { value exerted by this veg } \\
\text { type. }\end{array}$ \\
\hline RTE & & & $\begin{array}{l}\text { vegetation roughness equation for veg category - Tree: } \\
1 \text { Huthoff 2007-regard tree as rigid column } \\
2 \text { Cheng } 2011 \text {-regard tree as rigid column } \\
3 \text { Järvelä } 2004 \\
4 \text { Baptist } 2007 \\
5 \text { Luhar and Nepf } 2013 .\end{array}$ \\
\hline RSE & & & $\begin{array}{l}\text { vegetation roughness equation for veg category - Shrub: } \\
1 \text { Järvelä } 2004 \\
2 \text { Baptist } 2007 \\
3 \text { Luhar and Nepf } 2013 \\
4 \text { Rahmeyer } 2000 \\
5 \text { Fischenich } 2000 \\
6 \text { Whittaker } 2015 .\end{array}$ \\
\hline RGE & & & $\begin{array}{l}\text { vegetation roughness equation for veg category - Grass: } \\
1 \text { n-UR method } \\
2 \text { Kouwen and Li } 1980 .\end{array}$ \\
\hline \multirow[t]{17}{*}{ RPM } & & & $\begin{array}{l}\text { roughness parameters for the individual vegetation } \\
\text { roughness equation. }\end{array}$ \\
\hline & Huthoff 2007 & $\mathrm{Cd}$ & drag coefficient (unitless) \\
\hline & Cheng 2011 & $\mathrm{Cd}$ & drag coefficient (unitless) \\
\hline & \multirow[t]{7}{*}{ Järvelä 2004} & $\mathrm{Cd}$ & drag coefficient for leafless veg (unitless) \\
\hline & & RB & branching ratio of order $\mathrm{n}$ and order $\mathrm{n}+1$ (unitless) \\
\hline & & RD & diameter ratio of order $n$ and order $n+1$ (unitless) \\
\hline & & dmin & average diameter of branches of order 1 ( $\mathrm{ft}$ or $\mathrm{m}$ ) \\
\hline & & Ux & lowest velocity or reference velocity $(\mathrm{m} / \mathrm{s}$ or $\mathrm{ft} / \mathrm{s})$ \\
\hline & & Cdx & drag coefficient for leafy veg (unitless) \\
\hline & & $x$ & drag coefficient for leafy veg (unitless) \\
\hline & \multirow[t]{2}{*}{ Baptist 2007} & $\mathrm{Cd}$ & drag coefficient (unitless) \\
\hline & & $\mathrm{Cb}$ & Chézy resistance coefficient of the bed (unitless) \\
\hline & \multirow{2}{*}{$\begin{array}{l}\text { Luhar and } \\
\text { Nepf } 2013\end{array}$} & $\mathrm{Cd}$ & drag coefficient (unitless) \\
\hline & & $\mathrm{Cf}$ & $\begin{array}{l}\text { friction coefficient at the bed and the interface between } \\
\text { vegetation and open water (unitless) }\end{array}$ \\
\hline & \multirow[t]{3}{*}{$\begin{array}{l}\text { Rahmeyer } \\
2000\end{array}$} & & $\begin{array}{l}\text { four options available to compute modulus of plant stiffness - } \\
\text { Es }\end{array}$ \\
\hline & & & $\begin{array}{l}1=\text { use age }- \text { Es relationship } \\
2=\text { use age }- \text { F45 relationship } \\
3=\text { compute Es based on H/Ds } \\
4=\text { compute Es based on parameter Es_H_Ds. }\end{array}$ \\
\hline & & & $\begin{array}{l}\text { If option } 1 \text { or } 2 \text { is used, a relationship must be provided in the } \\
\text { following record "RRL". } \\
\text { If option } 4 \text { is used, record "RPM" must have two parameters: } \\
\text { option \# and value of Es_H_Ds. }\end{array}$ \\
\hline
\end{tabular}




\begin{tabular}{|c|c|c|c|}
\hline & $\begin{array}{l}\text { Fischenich } \\
2000\end{array}$ & & no parameter for this method \\
\hline & \multirow{2}{*}{$\begin{array}{l}\text { Whittaker } \\
2015\end{array}$} & $\mathrm{Cd}$ & drag coefficient (unitless) \\
\hline & & $\psi$ & Vogel exponent (unitless) \\
\hline & n-UR method & & no parameter \\
\hline & \multirow[t]{3}{*}{ Kouwen 1980} & & default $n$ value of this veg; option \# to compute MEl. \\
\hline & & & $\begin{array}{l}1 \text { = use equation provided by Kouwen and Li1980; } \\
2 \text { = use h-MEI relationship. }\end{array}$ \\
\hline & & & $\begin{array}{l}\text { If option } 2 \text { is choosen, h-MEl relationship should be provided } \\
\text { in the following record "RRL". }\end{array}$ \\
\hline \multirow[t]{6}{*}{ RDT } & & & $\begin{array}{l}\text { spatial and temporal data of LAI for Järvelä } 2004 \text { and CdAd } \\
\text { for Fischenich } 2000 \text {. }\end{array}$ \\
\hline & & & $\begin{array}{l}\text { There are } 4 \text { options for the spatial and temporal data. } \\
1=\text { constant value; } \\
2=\text { spatially varying data; } \\
3=\text { temporarily varying data; } \\
4=\text { spatially and temporarily varying data. }\end{array}$ \\
\hline & & & $\begin{array}{l}\text { If option } 1 \text { is chosen, two data must be provided for record } \\
\text { "RDT": option \# and the constant value. } \\
\text { If option } 2,3 \text { and } 4 \text { are chosen, "LAl.txt" for LAl and "CdAd.txt } \\
\text { for CdAd are required. Format of "LAl.txt" and "CdAd.txt": LAI } \\
\text { or CdAd value for vegetation type. }\end{array}$ \\
\hline & & "VVN": & $\begin{array}{l}\text { vegetation name, which must be consistent with the veg } \\
\text { name in vegetation.txt }\end{array}$ \\
\hline & & $\begin{array}{l}\text { "LAI" or } \\
\text { "CdA" }\end{array}$ & LAI value or CdAd value \\
\hline & & & $\begin{array}{l}\text { For only spatially varying data, specify their values for slice } \\
\text { polygons. For temporarily varying data or spatially and } \\
\text { temporarily varying data, } \\
\text { "NTM": number of time series. } \\
\text { "TIM": time points } \\
\text { "LAl" or "CdA": LAI value or CdAd value. } \\
\text { For only temporarily varying data, define a line of LAl or } \\
\text { CdAd time series. } \\
\text { For both spatially and temporarily varying data, define a line } \\
\text { of LAl or CdAd time series for each polygon. }\end{array}$ \\
\hline \multirow[t]{4}{*}{ RRL } & & & $\begin{array}{l}\text { relationship such as h-MEl and age-Es must be provided for } \\
\text { the following equations. }\end{array}$ \\
\hline & $\begin{array}{l}\text { Rahmeyer } \\
2000\end{array}$ & & age - Es relationship or age - F45 relationship \\
\hline & $\begin{array}{l}\text { Whittaker } \\
2015\end{array}$ & & h-El relationship \\
\hline & $\begin{array}{l}\text { Kouwen and } \\
\text { Li } 1980\end{array}$ & & h-MEI relationship \\
\hline
\end{tabular}

Soil and Groundwater Input Files. One soil input file and one groundwater input file are required to run RVSM.dll from HEC-RAS. "soilType_mapping_table.txt" includes Veg slice polygon ID, soil type ID within the polygon. "groundwater.txt" includes soil ID, hydraulic conductivity, capillary fringe height, maximum drop velocity, groundwater min and max heights listed in Table 7. 
Table 7. Groundwater simulation input parameters.

\begin{tabular}{|c|c|c|c|c|}
\hline Record & \multicolumn{2}{|l|}{ Parameter } & Units & Description \\
\hline GMT & \multicolumn{2}{|l|}{ Method } & & $0=$ none, $1=$ simulated \\
\hline \multirow[t]{6}{*}{ GHC } & \multirow{6}{*}{$\begin{array}{l}1 \text { to } \mathrm{N} \\
\text { (soil type) }\end{array}$} & type & & Soil type \\
\hline & & hc & $\mathrm{ft} /$ day & hydraulic conductivity \\
\hline & & hcap & $\mathrm{ft}$ & Height of capillary fringe \\
\hline & & hv & $\mathrm{ft} /$ day & Maximum drop velocity when the channel is dry \\
\hline & & $\mathrm{hmin}$ & $\mathrm{ft}$ & Groundwater minimum height \\
\hline & & $\mathrm{hmax}$ & $\mathrm{ft}$ & Groundwater maximum height \\
\hline
\end{tabular}

RVSM OUTPUTS. Four vegetation-related model output files and two error-check files are generated from running a HEC-RAS-RVSM model.

"veg_out.opt." At user-defined time steps, groundwater elevation, capillary elevation, and surface ground elevation, vegetation type, alive ID (which represents the plant is alive), the age, root crown elevation, height, diameter, and depth root below root crown for each polygon, are reported in this model output file. Each vegetation type is classified into ten height groups: 0 to $1 \mathrm{ft}, 1$ to $2 \mathrm{ft}, 2$ to $4 \mathrm{ft}, 4$ to $6 \mathrm{ft}, 6$ to $8 \mathrm{ft}, 8$ to $10 \mathrm{ft}, 10$ to $12 \mathrm{ft}, 12$ to $14 \mathrm{ft}, 14$ to $16 \mathrm{ft}$, and $>16 \mathrm{ft}$.

This output file provides detailed vegetation characteristic information at a user-specified time period, polygon ranges, and output interval. The format is Time, Veg slice polygon ID, surface or groundwater elevation, capillary fringe elevation, vegetation death ID, age, elevation of plant crown, plant height, stem diameter and root depth for each vegetation type.

"veg_sum_out.opt." This model output file includes the number of vegetation types. At userspecified time steps, vegetation area, the areas of dead vegetation due to different mortality mechanisms, including scour, burial, desiccation, inundation, senescence, and competition, are also included in the model output. Currently, each vegetation type is classified into nine age groups: 0 to 1,1 to 2,2 to 3,3 to 4,4 to 5,5 to 10,10 to 20,20 to 30 , and $>30$. Simulated vegetation areas for vegetation types and different age groups are reported at user-specified time steps. This output file summarizes vegetation area data for each time step and each vegetation type.

“veg_Man_out.opt.” RVSM-computed vegetation roughness coefficients (maximum, minimum and average) for each polygon are reported at user-specified time steps. If the user turns on vegetation roughness computation, this output file will be generated. Otherwise, this output file will not be generated. At a user-specified time step, this file lists the following two kinds of information: 1) Computed Manning's $n$ values for each polygon; the format is Time (day), polygon ID, Manning's $n$ value, and 2) minimum, maximum, and average calculated Manning's $n$ values for each vegetation type; the format is Time (day), vegetation type ID, maximum Manning's $n$ value, minimum Manning's $n$ value, average Manning's $n$ value.

"veg.hdf5." This is a compressed binary file that includes all the information described above three output files. It can be accessed and visualized using the HDFView software that can be downloaded from https://www.hdfgroup.org/downloads/hdfview/. 
SUMMARY: This document presented a summary of RVSM modeled riparian vegetation processes occurring in response to dynamic hydraulic conditions; this TN also summarizes hydraulic roughness prediction methods in RVSM, and their theoretical bases. HEC-RASRVSM is capable of modeling the interactions between flow and riparian vegetation in the floodplain. How stream flow directly affects riparian vegetation by the magnitude, duration, and hydraulics of inundation during floods and the magnitude and duration of droughts that affect water availability to plants during dry periods of the year can be quantified. How the characteristics and patterns of the riparian ecosystem respond to stream-flow changes are affected by the characteristics of sediment transport, plat attributes, and sediment mass balance of different rivers. This tool can also be used to address the following questions: 1) What impact does riparian vegetation have on local flood conditions? 2) What set of riverine operations can be used to encourage recruitment and survival of native vegetation (and control the spread of invasive species)? 3) How will management actions impact habitat for endangered and threatened species? In addition, the RVSM may be used to compute the dynamic Manning's $n$ for the HEC-RAS unsteady flow model and assist with flow model calibration.

The RVSM writes quantitative characteristics of modeled vegetation types within vegetation slice polygons at daily time steps; e.g., survival status, age, height, stem diameter, root depth, etc. The RVSM also generates vegetation statistical results, such as total area with living plants or area of dead plants for modeled vegetation types. Spatial distribution of vegetation types at any given date is created in model results and then can be used for model calibration and compared against vegetation mapping. The HEC-RAS-RVSM user interface is not yet available because it is still under development. The user must manually prepare all input files to run RVSM within HEC-RAS. The RVSM will be further developed to simulate plant density and biomass under the EMRRP. In the meantime, it will be integrated with the HEC-RAS 2-D flow model to simulate spatial and temporal changes of riparian vegetation in great detail.

ACKNOWLEDGEMENTS: The research presented in this technical note was developed under the EMRRP. The authors would like to acknowledge Mr. Steve Piper and Mr. Mark Jensen (HEC) and Dr. Junna Wang (University of California Davis) for integrating RVSM into HECRAS.

POINTS OF CONTACT: For additional information, contact Dr. Zhonglong Zhang (zhonglong.zhang@erdc.dren.mil) and Dr. Billy Johnson(billy.e.johnson@erdc.dren.mil) or the Program Manager of the EMRRP, Dr. Trudy Estes (601-634-2125, Trudy.J.Estes@usace.army.mil).This technical note should be cited as follows:

Zhang, Z., B. E. Johnson, and B. P. Greimann. 2019. HEC-RAS-RVSM (riparian vegetation simulation module). EMRRP Technical Notes Collection. ERDC/TN EMRRPSR-87. Vicksburg, MS: U.S. Army Engineer Research and Development Center.

\section{REFERENCES}

Baptist, M., V. Babovic, J. Rodriguez Uthurburu, M. Keijzer, R. Uittenbogaard, A. Mynett, and A. Verwey. 2007. On inducing equations for vegetation resistance. Journal of Hydraulic Research 45(4):435-450. https://doi.org/10.1080/00221686.2007.9521778. 


\section{ERDC/TN EMRRP-SR-87}

May 2019

Cheng, N. S. 2011. Representative roughness height of submerged vegetation. Water Resources Research 47(8): W08517. https://doi.org/10.1029/2011WR010590.

Chow, V. T., 1959. Open-channel hydraulics. New York, NY: McGraw-Hill.

Comerford, N. B, D. G. Neary, and R. S. Mansell. 1992. The effectiveness of buffer strips for ameliorating offsite transport of sediment, nutrients, and pesticides from silvicultural operations. New York, NY: National Council of the Paper Industry for Air and Stream Improvement Technical Bulletin 631.

Dosskey, M. G., P. Vidon, N. P. Gurwick, C. J. Allan, T. P. Duval, and R. Lowrance. 2010. The role of riparian vegetation in protecting and improving chemical water quality in streams. Journal of American Water Research Association 46(2):261-277.

Fischer, R. A., and J. C. Fischenich. 2000. Design recommendations for riparian corridors and vegetated buffer strips. Technical Report No. ERDC/TN-EMRRP-SR-24. Vicksburg, MS: U.S. Army Engineer Research and Development Center.

Fotherby, L., J. V. Huang, and B. P. Greimann. 2012. Vegetation Modeling with SRH-1DV: Predicting the Interactions between Flow, Sediment, and Riparian Vegetation Research and Development. Technical Report No. SRH-2013-09. Denver, CO: U.S. Bureau of Reclamation Technical Service Center.

Freeman, G. E., W. J. Rahmeyer, and R. R. Copeland. 2000. Determination of Resistance Due to Shrubs and Woody Vegetation. ERDC/CHL TR-00-25. Vicksburg, MS: U.S. Army Engineer Research and Development Center.

Hulshof, C. M., N. G., Swenson, and M. D. Weiser. 2015. Tree height-diameter allometry across the United States. Ecology and Evolution 5(6):1193-1204. https://doi.org/10.1002/ece3.1328.

Järvelä, J. 2004. Determination of low resistance caused by non-submerged woody vegetation. International Journal of River Basin Management 2(1):61-70. https://doi.org/10.1080/15715124.2004.9635222.

Kouwen, N. 1988. Field estimation of the biomechanical properties of grass. Journal of Hydraulic Research 26(5):559-568. https://doi.org/10.1080/00221688809499193.

Kouwen, N., and M. Fathi-Moghadam. 2000. Friction factors for coniferous trees along rivers. Journal of Hydraulic Engineering 126(10):732-740. https://doi.org/10.1061/(ASCE)0733-9429(2000)126:10(732).

Kouwen, N., and R. M. Li. 1980. Biomechanics of vegetative channel linings. Journal of the Hydraulics Division 106(HY6):1085-1103.

Luhar, M., and H. M. Nepf. 2013. From the blade scale to the reach scale: A characterization of aquatic vegetative drag. Advances in Water Resources 51:305-316. https://doi.org/10.1016/j.advwatres.2012.02.002.

McKay, S. K., and J. C. Fischenich. 2011. Robust prediction of hydraulic roughness. ERDC/CHL CHETN-VII-11. Vicksburg, MS: U.S. Army Engineer Research and Development Center.

Merritt, D. M., M. L. Scott, P. LeRoy, G. T. Auble, and D. A. Lytle. 2010. Theory, methods and tools for determining environmental flows for riparian vegetation: riparian vegetation-flow response guilds. Freshwater Biology 55(1):206-225. https://doi.org/10.1111/j.1365-2427.2009.02206.x.

Perucca, E., C. Camporeale, and L. Ridolfi. 2007. Significance of the riparian vegetation dynamics on meandering river morphodynamics. Water Resources Research 43(3). https://doi.org/10.1029/2006WR005234.

Ree, W. 1954. Handbook of channel design for soil and water conservation: U.S. Dept. of Agriculture, Soil Conservation Service. SCS-TP-61. Stillwater, OK: Stillwater Outdoor Hydraulic Laboratory in cooperation with the Oklahoma Agricultural Experiment Station.

Rood, S. B., G. M. Samuelson, J. H. Braatne, C. R. Gourley, F. M. Hughes, and J. M. Mahoney. 2005. Managing river flows to restore floodplain forests. Frontiers in Ecology and the Environment 3(4):193-201. https://doi.org/10.1890/1540-9295(2005)003[0193:MRFTRF]2.0.CO;2.

Tabacchi, E., D. L. Correll, R. Hauer, G. Pinay, A. M. Planty-Tabacchi, and R. C. Wissmar. 1998. Development, maintenance and role of riparian vegetation in the river landscape. Freshwater Biology 40:497-516. https://doi.org/10.1046/j.1365-2427.1998.00381.x. 
Tal, M., K. Gran, A. B. Murray, C. Paola, and D. M. Hicks. 2004. Riparian vegetation as a primary control on channel characteristics in multi-thread rivers. In: Riparian vegetation and fluvial geomorphology: hydraulic, hydrologic, and geotechnical interaction, ed. S. J. Bennett and A. Simon. American Geophysical Union Monograph: 43-58.

U.S. Bureau of Reclamation (USBR). 2009. Calibration of Numerical Models for the Simulation of Sediment Transport, River Migration, and Vegetation Growth on the Sacramento River, California. Technical Report No. SRH-2009-27. Denver, Colorado: Bureau of Reclamation, Technical Service Center.

Whittaker, P., C. A. Wilson, and J. Aberle. 2015. An improved Cauchy number approach for predicting the drag and reconfiguration of flexible vegetation. Advances in Water Resources 83:28-35. https://doi.org/10.1016/j.advwatres.2015.05.005.

Wu, W. 2007. Computational River Dynamics. London, UK: Taylor and Francis.

NOTE: The contents of this technical note are not to be used for advertising, publication, or promotional purposes. Citation of trade names does not constitute an official endorsement or approval of the use of such products. 